\title{
T Cell-Depleted Donor Lymphocyte Infusion
}

National Cancer Institute

\section{Source}

National Cancer Institute. I Cell-Depleted Donor Lymphocyte Infusion. NCI Thesaurus.

Code C116473.

The removal of T-cells from the donor's lymphocyte specimen prior its transfusion into the recipient. 